for voting papers but would also help to ensure that those who have a right to receive voting papers receive them in time to record their votes.

\section{The Night Sky in May}

NEw moon occurs on May 1ld. 20h. 21m. U.T., and full moon on May 27d. 01h. $49 \mathrm{~m}$. The following conjunctions with the moon take place: May 8d. 16h., Mars $4^{\circ}$ N. ; May 9d. 11h., Venus $7^{\circ}$ N. ; May 9d. 23h., Mercury $2^{\circ}$ N.; May 15d. 03h., Saturn $0.2^{\circ}$ S. ; May $2 \mathrm{Cd}$. $11 \mathrm{lh}$., Jupiter $4^{\circ} \mathrm{S}$. Occultations of stars brighter than magnitude 6 are as follows : May 15d. 20h. 23.2m., $\delta$ Gemi. $(D)$; May 15d. $20 \mathrm{~h}$. $56 \cdot 4 \mathrm{~m} ., \delta$ Gemi. $(R)$; May 16d. 2lh. 27.0m., $49 \mathrm{~B}$. Canc. $(D)$. The times refer to the latitude of Greenwich and $D$ and $R$ refer to disappearance and reappearance respectively. Mercury rises about half an hour before sunrise throughout the month and will not be an easy object to observe. It reaches its greatest westerly elongation on May 11 . Venus is conspicuous in the eastern sky, rising an hour before the sun on May 1 and about an hour and a quarter before the sun on May 31. The planet is stationary on May 4 and May 24. Jupiter can be seen throughout the early morning hours, setting at $3 \mathrm{~h}$. Ilm., $2 \mathrm{~h} .15 \mathrm{~m}$. and $1 \mathrm{~h} .10 \mathrm{~m}$. at the beginning, middle and end of the month, respectively. Saturn is becoming more difficult to observe as it sets at midnight on May 1 and at 22h. 26m. on May 31. The $\eta$ Aquarid meteor. shower is due in the early part of May. The meteors appear in the early morning hours but moonlight will interfere with observations.

\section{Comments on Chromosome Structure}

IN Nature of April 21, p. 471, an article by Dr. I. Manton under this title was published. The accompanying illustration, however, was very unsatisfactory, due apparently to defects in the block. Accordingly a new block was prepared and the illustra. tion is repeated below, with the explanatory legend.

\section{Announcements}

SIR John ORR, professor of agriculture in the University of Aberdeen, has been elected a member of Parliament for the Scottish universities, taking the place of Mr. G. A. Morrison, who has resigned.

The following appointments have been made in the University of London :

Dr. Edmund Giffen, since 1940 director of research at the Institution of Automobile Engineers, to the University chair of civil and mechanical engineering tenable at Queen Mary College, from October 1, 1945.

Prof. Harold Davenport, professor of mathematics at University College, Bangor, to the Astor chair of mathematics at University College, from October 1, 1945.

Dr. Norman Wright, director of the Hannah Dairy Research Institute, who has been undertaking a survey of the livestock in the Middle East territories during the past five months, has interrupted his tour in order to make a brief visit to Ceylon, where he is to advise the Ceylon Government on the future development of the cattle and dairy industries of the island. Dr. Wright will shortly resume his Middle East tour. $\mathrm{He}$ is expected back in Great Britain by the end of June.

THE International Commission on Zoological Nomenclature announces the election of Dr. James L. Peters, curator of birds, Museum of Comparative Zoology at Harvard College (assistant secretary to the Commission), to be vice-president of the Com. mission in succession to the late Dr. C. W. Stiles, Smithsonian Institution, Washington.

THe following appointments have recently been made in the Colonial Services: J. E. Cobby, to be assistant conservator of forests, Kenya; K. G. N. Willcocks, to be government chemist, Gold Coast; H. Hirst, acting director of agriculture, Malta, to be assistant director of agriculture, Cyprus.

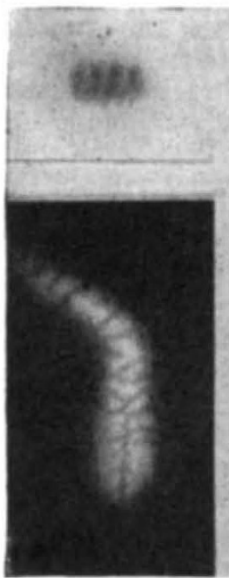

3

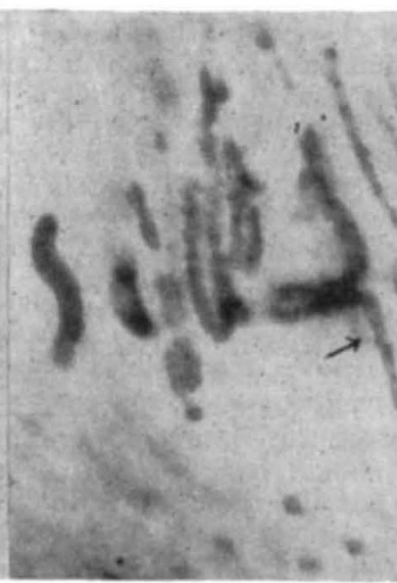

$+8$

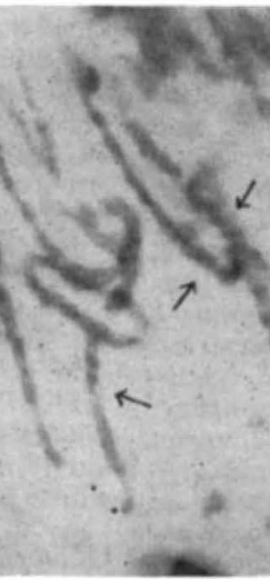

4
2

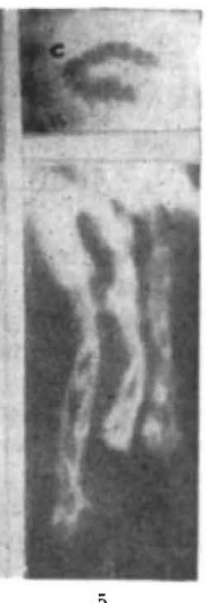

Fig. 1. Unpaired chromosome of Osmunda at the flrst meiotic division after ammonia treatment for spiral structure. Acetocarmine preparation photographed in clove oil by visual light. $(\times 2000$.

Fig. 2. Split chromosome at the second meiotic division in Osmunda after ammonia treatment for spiral structure, the two chromatids are attached only at the centromere $(c)$. Acetocarmine preparation, ultra-violet photograph. $(\times 2000$.)

Fig. 3. Split chromosome at metaphase of the third spore division in Osmunda showing spiral structure without special treatment. Acetocarmine preparation, ultra-violet photograph $(\times 4000)$ negative print (the positive of this and others in Manton and Smiles, $\left.1943^{5}\right)$. Fig. 4. Anaphase of the flrst spore division in Osmundx flxed 30 hours after irradiation of the uninucleate spore with X-rays at 2,500 r. showing fractures, fusions and abnormally clear spiral structure. Acetocarmine preparation, visual light photograph. ( $x$ 1000.)

Fig. 5. Anaphase of the third spore division in Todea after ammonia treatment, showing lateral separation of component strands. Acetocarmine preparation, ultra-violet photograph ( $\times 4000)$, negative print (the positive of this and other chromosomes in Manton, $\left.1945^{\circ}\right)$. 